E-ISSN : 2549-6581

OPEN ACCESS

Journal of Issues in

Artikel Hasil Penelitian

Diterima : 02 Juli 2018

Direview : 02 Juli 2018

Dimuat : Agustus - November 2018

\title{
Perbedaan Pengaruh Metode Simulation Game (SIG) dengan Audio Visual terhadap Peningkatan Pengetahuan Kesehatan Reproduksi Remaja Putri di SMK Negeri 1 Pujon
}

\author{
Hanifah Asgi Nur Azizah ${ }^{1 *}$, Coryna Rizky Amelia ${ }^{1}$, Mustika Dewi ${ }^{1}$ \\ ${ }^{1 *)}$ Program Studi S1 Kebidanan, Fakultas Kedokteran, Universitas Brawijaya, \\ Email : hanifazizah20@gmail.com \\ HP : 085713741257
}

\begin{abstract}
Reproductive health problems in adolescents occurs because teenagers lack knowledge of reproductive health. The results of preliminary study on class $X$ by giving a short question through interviews showed that $70 \%$ students of them have less knowledge level about reproductive health especially about young age marriage and HIV. Therefore it is takes socialization efforts with simulation game and audio visual method as an effort to improve students' knowledge about young marriage and HIV / AIDS. This research aims to analyzed difference in the influence of counseling method of simulation game with audio visual to increase knowledge of reproductive health of young women in SMK Negeri 1 Pujon. The research design was true-experimental, pre-test and post-test control group design. The population in this research were all students of class $X$ SMK Negeri 1 Pujon amounted to 89 students, the sample used 50 students by using simple random sampling technique. The results showed that there were differences between the simulation game method and audio visual to increase the knowledge of $X$-class girls about reproductive health $(p=0,041)$. The simulation game method has more effective to increase the knowledge of the girls than the audio visual, because the average score of game simulation knowledge is higher than the average score audio visual (4.80>3.16).
\end{abstract}

Keywords: audio visual, HIVIAIDS, knowledge inprovement, simulation game, young marriage.

\section{ABSTRAK}

Masalah kesehatan reproduksi pada remaja terjadi karena kurangnya pengetahuan mengenai kesehatan reproduksi. Hasil dari studi pendahuluan pada kelas $X$ dengan memberikan pertanyaan singkat melalui wawancara menunjukkan bahwa $70 \%$ siswa diantaranya memiliki tingkat pengetahuan yang kurang mengenai kesehatan reproduksi khususnya tentang pernikahan usia muda dan HIV. Sehingga diperlukan upaya sosialisasi dengan metode simulation game dan audio visual sebagai upaya untuk meningkatkan pengetahuan siswa mengenai pernikahan usia muda dan HIV/AIDS. 
Penelitian ini bertujuan untuk menganalisa perbedaan pengaruh penyuluhan metode simulation game dengan audio visual terhadap peningkatan pengetahuan kesehatan reproduksi remaja putri di SMK Negeri 1 Pujon Kabupaten Malang. Rancangan penelitian dengan true-experimental, desain penelitian yang digunakan yaitu pre test-post test control group design. Populasi pada penelitian ialah semua siswi kelas X SMK Negeri 1 Pujon sebanyak 89 siswa, sampel menggunakan 50 siswi dipilih dengan teknik simple random sampling. Hasilnya menunjukkan terdapat perbedaan pengaruh metode simulation game dengan audio visual terhadap peningkatan pengetahuan remaja putri kelas $X$ tentang kesehatan reproduksi $(p=0,041)$. Metode simulation game lebih berpengaruh terhadap peningkatan pengetahuan remaja putri daripada metode audio visual, karena rata-rata skor pengetahuan simulation game lebih tinggi dari rata-rata skor audio visual $(4,80>3,16)$.

Kata kunci: audio visual, HIV/AIDS, peningkatan pengetahuan, simulation game, pernikahan usia muda.

*Korespondensi: Hanifah Asgi Nur Azizah. Surel: hanifazizah20@gmail.com 


\section{PENDAHULUAN}

Masa remaja merupakan periode terjadinya pertumbuhan dan perkembangan yang pesat baik secara fisik, psikologis maupun intelektual. Remaja mulai memandang diri dengan penilaian dan standar pribadi, tetapi penilaian dalam interpretasi hubungan sosialnya masih kurang ${ }^{[1]}$. Remaja harusnya mengetahui kesehatan reproduksi supaya memiliki informasi yang benar mengenai proses reproduksi serta berbagai faktor yang ada disekitarnya ${ }^{[2]}$.

Berdasarkan perolehan SDKI 2012, 17 persen perempuan pernah kawin yang berusia 20 sampai 24 tahun mengatakan mereka menikah kurang dari usia 18 tahun. Perkawinan diantara anak-anak berumur 15 tahun sebesar 3 persen. $\mathrm{Hal}$ itu merujuk jika risiko pernikahan usia anak meningkat ke remaja yang lebih tua. Angka kejadian perkawinaan anak perempuan usia 15-19 tahun di provinsi Jawa Timur sebesar 16,7 persen. Di Kabupaten Malang, persentase pernikahan remaja perempuan usia muda diketahui mencapai 27,11 persen ${ }^{[3]}$.

Data yang diperoleh Kementerian Kesehatan RI mengungkapkan semenjak April sampai Juni 2016, banyak kejadian Acquired Immune Deficiency Syndrome (AIDS) baru yang didata adalah 3.267 kasus dari 34 provinsi. Adapun pada kelompok umur 15-19 tahun dengan jumlah 106 kasus. Wilayah Jawa Timur termasuk ke dalam sepuluh provinsi dengan jumlah AIDS terbanyak yaitu sebanyak 629 kasus $^{[4]}$. Kabupaten Malang sendiri terdapat 104 kasus dengan kasus HIV lebih banyak dari pada Kota Malang ${ }^{[5]}$.
Program

pendidikan

kesehatan reproduksi bagi remaja selama ini menggunakan media sebagai komponen pembelajaran. Metode pembelajaran yang dapat digunakan antara lain audio visual, curah pendapat, studi kasus, debat, diskusi kelompok besar, permainan, dan lain-lain. Audio visual merupakan salah satu media yang menyajiikan informasi atau pesan secara audio dan visual ${ }^{[6]}$. Simulation game (SIG) merupakan memodifikasi dari metode permainan simulasi ${ }^{[7]}$.

Pada penelitian Nanda (2012) yang berjudul perbedaan pengaruh metode focus group discussion (FGD) dengan metode simulation game (SIG) terhadap peningkatan pengetahuan siswa kelas XI tentang kesehatan reproduksi remaja (KRR) di SMK Hidayah Semarang tahun 2012 didapatkan hasil bahwa metode simulation game (SIG) lebih berpengaruh dibandingkan metode focus group discussion (FGD).

Menurut penelitian Nur Puspita Sari (2015) yang berjudul studi komparasi penyuluhan audio visual dan peer group terhadap tingkat pengetahuan kesehatan reproduksi remaja di SMP $\mathrm{N} 1$ Ngaglik Sleman Yogyakarta tahun 2015 menunjukkan bahwa metode audio visual lebih efektif dibandingkan dengan peer group.

Peneliti memilih tempat penelitian di SMK Negeri 1 Pujon, karena daerah tersebut menjadi salah satu dari lima Kecamatan dengan kalkulasi mencapai 8.100 pasangan yang menikah di usia dini pada tahun 2013. Sedangkan untuk angka kejadian HIV/AIDS setelah dilakukan kunjungan konseling, dan tes maka ditemukan sebanyak 4 orang positif HIV pada bulan April- 
Juni 2016. Berdasarkan observasi awal tanggal 17 Juli 2017 di SMK N 1 Pujon pada kelas $X$ dengan memberikan pertanyaan singkat melalui wawancara menunjukkan bahwa $70 \%$ diantaranya memiliki tingkat pengetahuan yang kurang mengenai kesehatan reproduksi khususnya tentang pernikahan usia muda dan HIV.

Tujuan penelitian yang akan dilakukan adalah mengetahui perbedaan pengaruh penyuluhan metod Simulation Game (SIG) dengan audio visual terhadap peningkatan pengetahuan kesehatan reproduksi remaja putri di SMK Negeri 1 Pujon Kabupaten Malang dan mengetahui apakah metode simulation game lebih berpengaruh dalam penyuluhan untuk meningkatkan pengetahuan siswi tentang kesehatan reproduksi khususnya pernikahan usia muda dan HIV/AIDS dibandingkan dengan metode simulation game.

\section{METODE PENELITIAN}

\section{Rancangan/Desain Penelitian}

Penelitian ini menggunakan desain true-experimental dengan rancangan penelitian pre test-post test control group design. Pengumpulan data dengan cara metode kuesioner yang diberikan pada pre test dan post test.

\section{Sumber Data}

Data diperoleh dari kuesioner pre test dan post test yang dilakukan di Sekolah Menengah Kejuruan Negeri 1 Pujon Kabupaten Malang selama rentang waktu satu bulan pada bulan Oktober 2017.

\section{Sasaran Penelitian}

Populasi pada penelitian ini yaitu seluruh siswi kelas $X$ SMK Negeri 1 Pujon Kabupaten Malang yang berjumlah 89 orang. Teknik pengambilan sampel dalam penelitian ini adalah teknik simple random sampling dengan sampel pada masing-masing kelompok penelitian adalah 25 orang, karena dalam penelitian ini ada dua kelompok yaitu kelompok eksperimen dan kelompok pembanding, sehingga jumlah sampel yaitu 50 orang.

\section{Pengembangan Instrumen dan Teknik Pengumpulan Data}

Alat dan instrumen yang

digunakan pada penelitian ini adalah sebagai berikut:

1. Media penyuluhan simulation game dan audio visual: Media simulation game dan audio visual ini di buat berdasarkan tinjauan teoritis. Media ini berisi tentang penjelasan pernikahan usia muda, faktor-faktor yang mempengaruhi pernikahan usia muda, dampak dari pernikahan usia muda, dan upaya pencegahan pernikahan usia muda, serta membahas mengenai HIV/AIDS. Media simulation game berupa permainan ular tangga yang didalam terdapat beberapa pertanyaan yang harus dijawab oleh subyek.

2. Kuesioner penelitian: Kuesioner yang digunakan dalam penelitian ini bertujuan untuk mengukur tingkat pengetahuan kesehatan reproduksi. Kuesioner tersebut berupa pre test dan post test penyuluhan yang kontennya sama. Kuesioner berisi identitas responden serta pertanyaan tentang pernikahan 
usia muda dan penyakit HIV/AIDS sejumlah 20 soal dan telah diuji reliabilitas dan validitasnya.

3. Lembar informed consent yang menyatakan bahwa siswa bersedia menjadi responden penelitian.

Dalam penelitian ini pemberian perlakuan pada masingmasing kelompok dilakukan pada hari yang sama. Teknik pelaksanaan pengambilan data dilakukan dengan mengumpulkan subjek penelitian untuk diberikan penyuluhan dengan metode dan media yang berbeda sesuai dengan masing-masing kelompok. Kelompok eksperimen diberikan penyuluhan melalui metode simulation gameyang menggunakan alat berupa papn ular tangga yang akan dimainkan oleh subyek, akan mengerjakan pre test, mendapatkan intervensi, lalu melakukan post test. Post test dan pre-test dilakukan selama 30 menit serta penyuluhan dengan metode simulation game dilaksanakan selama 40 menit. Sedangkan kelompok pembanding diberikan penyuluhan dengan audio visual, akan mendapat pre test, memperoleh intervensi, dan melaksanakan posttest. Post test dan pre test dilakukan selama 30 menit serta penyuluhan dengan metode audio visual dilaksanakan selama 20 menit.

\section{Teknik Analisis Data}

Analisis data yang digunakan yaitu analisi univariat dan analisa bivariat melalui uji statistika menggunakan uji normalitas data dengan uji Shapiro-Wilk. Hasil data menunjukkan nilai $p>0,05$ maka data dikatakan berdistribusi normal. Karena data berdistribusi normal, untuk mengetahui perbedaan tingkat pengetahuan sebelum dan sesudah tindakan menerapkan uji paired $t$ test. Sedangkan uji Independent ttest digunakan untuk mengetahui perbedaan penyuluhan kesehatan yang diberikan menggunakan metode simulation game dan audio visual.

\section{Ethical Clearance}

Penelitian ini telah dinyatakan laik etik oleh Komisi Etik Penelitian Kesehatan Fakultas Kedokteran Universitas Brawijaya dengan Surat Keterangan Laik Etik No. 319/EC/KEPK-S1-KB/09/2017

\section{HASIL PENELITIAN}

Tingkat Pengetahuan Kesehatan Reproduksi Remaja Putri Sebelum dan Setelah Penyuluhan dengan Metode Simulation Game Berikut ini merupakan distribusi frekuensi dan persentase tingkat pengetahuan kesehatan reproduksi remaja putri sebelum dan setelah penyuluhan dengan metode simulation game: 
Tabel 1. Distribusi Frekuensi dan Persentase Tingkat Pengetahuan Responden Sebelum dan Setelah Penyuluhan dengan Metode Simulation Game

\begin{tabular}{|c|c|c|c|c|c|c|}
\hline \multirow[b]{3}{*}{ SGE } & \multicolumn{5}{|c|}{ SGO } & \multirow{2}{*}{ Total } \\
\hline & & \multicolumn{2}{|c|}{ Kurang } & Cukup & Baik & \\
\hline & \multirow{2}{*}{ Kurang } & $\mathrm{n}$ & 0 & 8 & 3 & 11 \\
\hline & & $\%$ & 0 & 32 & 12 & 44 \\
\hline & \multirow{2}{*}{ Cukup } & $\mathrm{n}$ & 1 & 6 & 6 & 13 \\
\hline & & $\%$ & 4 & 24 & 24 & 52 \\
\hline & \multirow{2}{*}{ Baik } & $\mathrm{n}$ & 0 & 0 & 1 & 1 \\
\hline & & $\%$ & 0 & 0 & 4 & 4 \\
\hline \multirow[t]{2}{*}{ Total } & & $\mathrm{n}$ & 1 & 14 & 10 & 25 \\
\hline & & $\%$ & 4 & 56 & 40 & 100 \\
\hline
\end{tabular}

Keterangan tabel :

SGE : Simulation Game Pre test

SGO : Simulation Game Pos test

$\mathrm{n} \quad$ : Besarnya sampel

Berdasarkan tabel 1 terlihat distribusi perubahan kategori tingkat pengetahuan remaja putri tentang kesehatan reproduksi pada saat sebelum dan setelah mendapatkan penyuluhan dengan metode simulation game. Sejumlah 44\% responden pada saat pre test berada dalam kategori berpengetahuan kurang, setelah dilakukan post test terdapat $12 \%$ yang berubah menjadi kategori baik, dan sebanyak $32 \%$ tetap dalam kategori cukup. Selanjutnya, sebanyak $52 \%$ Sedangkan $4 \%$ responden lain pada saat pre test dalam kategori baik dan pada saat post test tetap dalam kategori baik.

Tingkat Pengetahuan Kesehatan Reproduksi Remaja Putri Sebelum dan Setelah Penyuluhan dengan Metode Audio Visual

Berikut ini merupakan distribusi frekuensi dan persentase tingkat pengetahuan kesehatan reproduksi remaja putri sebelum dan setelah penyuluhan dengan metode audio visual:

Tabel 2. Distribusi Frekuensi dan Persentase Tingkat Pengetahuan Responden Sebelum dan Setelah Penyuluhan dengan Metode Audio Visual

\begin{tabular}{|c|c|c|c|c|c|c|}
\hline & \multicolumn{5}{|c|}{ AVO } & \multirow{2}{*}{ Total } \\
\hline & & & & Cukup & Baik & \\
\hline \multirow[t]{6}{*}{ AVE } & \multirow{2}{*}{ Kurang } & $\mathrm{n}$ & 0 & 9 & 4 & 13 \\
\hline & & $\%$ & 0 & 36 & 16 & 52 \\
\hline & \multirow{2}{*}{ Cukup } & $n$ & 1 & 7 & 4 & 12 \\
\hline & & $\%$ & 4 & 28 & 16 & 48 \\
\hline & \multirow{2}{*}{ Baik } & $n$ & 0 & 0 & 0 & 0 \\
\hline & & $\%$ & 0 & 0 & 0 & 0 \\
\hline \multirow[t]{2}{*}{ Total } & & $\mathrm{n}$ & 1 & 16 & 8 & 25 \\
\hline & & $\%$ & 4 & 64 & 32 & 100 \\
\hline
\end{tabular}


Keterangan tabel :

AVE : Audio Visual Pre test

AVO : Audio Visual Pos test

$\mathrm{n} \quad$ : Besarnya sampel

Berdasarkan tabel 2 terlihat distribusi perubahan kategori tingkat pengetahuan remaja putri tentang kesehatan reproduksi pada saat sebelum dan setelah mendapatkan penyuluhan dengan metode audio visual. Sebanyak $52 \%$ responden pada saat pre test berada dalam kategori berpengetahuan kurang, setelah dilakukan post test sebanyak $16 \%$ yang berubah menjadi kategori baik dan 36\% responden menjadi kategori cukup. Selanjutnya, sebanyak $48 \%$ responden pada saat pre test berada dalam kategori cukup, setelah dilakukan post test sebanyak $16 \%$ berubah menjadi kategori baik, $28 \%$ tetap dalam kategori cukup, dan $4 \%$ responden yang kategori pengetahuannya turun menjadi kurang.

\section{Analisis Statistik Deskriptif Metode Simulation Game dan Metode Audio Visual}

Sebelum melakukan analisis data peneliti melakukan uji normalitas penelitian terlebih dahulu. Berdasarkan hasil pengujian normalitas menggunakan uji Shapiro-Wilk, didapatkan nilai signifikansi sebesar 0,139 dimana jumlah tersebut lebih besar dari 0,05 $(p>0,05)$ sehingga menunjukkan data berdistribusi normal. Maka data hasil penelitian dianalisis dengan uji parametrik yaitu dengan uji paired $t$ test dan uji independent $t$ test untuk mengetahui metode paling berpengaruh terhadap tingkat pengetahuan remaja putri tentang kesehatan reproduksi.
Berikut ini merupakan analisis data deskriptif tingkat pengetahuan kesehatan reproduksi remaja putri sebelum, setelah penyuluhan dengan metode simulation game:

Tabel 3. Analisis Statistik Deskriptif Tingkat Pengetahuan

Remaja Putri Sebelum dan Setelah Penyuluhan dengan Metode Simulation Game

Berdasarkan tabel 3 dapat dikatakan bahwa terjadi peningkatan rata-rata skor pengetahuan remaja putri tentang kesehatan reproduksi sebelum dan setelah mendapatkan penyuluhan menggunakan simulation game yang berupa permainan ular tangga. Peningkatan tersebut terlihat dari rata-rata skor pre test yaitu 10,60 yang kemudian meningkat menjadi 15,40 pada saat

\begin{tabular}{cccc}
\hline & Mean & $\begin{array}{c}\text { Standar } \\
\text { Deviasi }\end{array}$ & $\begin{array}{c}p- \\
\text { value }\end{array}$ \\
\hline Pre Test & 10,60 & 2,466 & 0,000 \\
Post & 15,40 & 2,380 & \\
Test & & & \\
\hline
\end{tabular}

post test. Selisih rata-rata skor pre test dan post test tersebut sebesar 4,8 .

Hasil uji paired $t$ test pada simulation game didapatkan nilai $p$ value senilai 0,000 . Nilai ini lebih rendah daripada nilai a sebesar 0,05 . Sehingga dapat diambil kesimpulan jika ada perbedaan yang signifikan tentang pengetahuan siswa antara sebelum dan setelah intervensi pada kelompok simulation game. 
Berikut ini merupakan analisis data deskriptif tingkat pengetahuan kesehatan reproduksi remaja putri sebelum dan setelah penyuluhan dengan metode audio visual:

Tabel 4. Analisis Statistik Deskriptif Tingkat Pengetahuan

Remaja Putri Sebelum dan

Setelah Penyuluhan dengan Metode Audio Visual

\begin{tabular}{cccc}
\hline & Mean & $\begin{array}{c}\text { Standar } \\
\text { Deviasi }\end{array}$ & $p$-value \\
\hline Pre Test & 11,48 & 2,312 & 0,000 \\
Post & 14,64 & 2,307 & \\
Test & & & \\
\hline
\end{tabular}

Berdasarkan tabel 4 dapat dikatakan bahwa terjadi peningkatan rata-rata skor pengetahuan remaja putri tentang kesehatan reproduksi sebelum dan setelah mendapatkan penyuluhan menggunakan metode audio visual. Peningkatan tersebut terlihat dari rata-rata skor pre test yaitu 11,48 yang kemudian meningkat menjadi 14,64 pada saat post test. Selisih rata-rata skor pre test dan post test tersebut sebanyak 3,16 .

Hasil uji paired $t$ test pada audio visual didapatkan nilai $p$-value sebanyak 0,000. Nilai ini lebih kecil dari nilai a sebesar 0,05 . Sehingga disimpulkan yaitu ada perbedaan yang signifikan tentang pengetahuan siswa antara sebelum dan setelah intervensi pada kelompok audio visual.

\section{Perbedaan Metode Simulation Game dan Audio Visual Terhadap Tingkat Pengetahuan Kesehatan Reproduksi Remaja Putri}

Berikut ini merupakan perbedaan metode simulation game dan metode audio visual terhadap tingkat pengetahuan kesehatan reproduksi remaja putri:

Tabel 5. Perbedaan Metode

Simulation Game dan Audio

Visual Terhadap Tingkat

Pengetahuan Kesehatan

Reproduksi Remaja Putri

\begin{tabular}{ccc}
\hline Metode & Mean & $p$-value \\
Penyuluhan & & \\
\hline Simulation Game & 4,80 & 0,041 \\
Audio Visual & 3,16 & 0,041 \\
\hline
\end{tabular}

Berdasarkan tabel 5 dapat dilihat dari hasil uji independent $t$ test menunjukkan nilai $p$-value sebesar 0,041. Nilai signifikansi tersebut lebih kecil dari $\alpha=0,05$ sehingga metode simulation game dan metode audio visual berpengaruh terhadap peningkatan pengetahuan kesehatan reproduksi remaja putri. Dimana rata-rata skor pengetahuan, kelompok penyuluhan metode audio visual lebih kecil yaitu 3,16 dibandingkan kelompok penyuluhan metoe simulation game yaitu 4,80 sehingga simulation game lebih berpengaruh terhadap peningkatan pengetahuan remaja putri tentang kesehatan reproduksi di SMK Negeri 1 Pujon Kabupaten Malang.

\section{PEMBAHASAN}

Keberhasilan metode simulation game khususnya permainan ular tangga (snake ladder) dalam meningkatkan pengetahuan remaja putri tentang kesehatan reproduksi mengenai pernikahan usia muda dan HIV/AIDS dapat disebabkan karena kelebihan atau keunggulan yang dimiliki oleh permainan ular tangga tersebut. Keunggulan yang ada dalam permainan ular tangga berupa menyingkirkan keseriusan 
yang mencegah di mana harus ada keseimbangan antara suasana yang menyenangkan dan keseriusan, meningkatkan semangat dalam belajar sehingga anak termotivasi untuk mengikuti proses belajar, dan anak-anak akan menjadi semakin konsentrasi dengan materi yang dilibatkan dalam permainan ${ }^{[9]}$.

Peningkatan

pengetahuan

remaja putri tentang kesehatan reproduksi terutama mengenai pernikahan usia muda dan HIV/AIDS dapat terjadi karena dengan melihat gambar akan sekaligus mendengarkan suara maka akan lebih cepat mengerti tentang apa yang dijelaskan, sehingga salah pengertian dapat dihindari secara efektif, memberikan dorongan dan motivasi serta melalui metode audio visual akan lebih lama terekam dalam ingatan, sehingga memudahkan siswa dalam mengamati dan menirukan pembelajaran yang diajarkan ${ }^{[10]}$.

Peningkatan pengetahuan dengan penyuluhan menggunakan media permainan ular tangga dapat dilihat dari peningkatan rata-rata skor pengetahuan awal (pre-test) sebesar 12,48 yang kemudian berubah menjadi 22,12 pada saat post-test ${ }^{[11]}$.

Rata-rata selisih skor pengetahuan kesehatan reproduksi sebelum dan setelah dilakukan penyuluhan dengan metode simulation game sebesar 4,80. Sedangkan pada kelompok penyuluhan dengan metode audio visual rata-rata selisih skor pengetahuan kesehatan reproduksi sebelum dan setelah dilakukan penyuluhan adalah 3,16. Hal ini menunjukkan terdapat perbedaan yang signifikan setelah pemberian penyuluhan memakai metode simulation game dan audio visual terhadap peningkatan pengetahuan kesehatan reproduksi remaja putri, dan dapat disimpulkan bahwa simulation game lebih menentukan dalam meningkatkan pengetahuan kesehatan reproduksi remaja putri daripada metode audio visual dilihat berdasarkan peringkat rata-rata setelah pemberian penyuluhan.

Kelompok metode simulation game dan kelompok metode audio visual memiliki perbedaan yang signifikan dalam peningkatan pengetahuan kesehatan reproduksi, tetapi keduanya memberikan pengaruh dalam peningkatan pengetahuan kesehatan reproduksi remaja putri. Sehingga dapat disimpulkan bahwa metode simulation game dan metode audio visual dapat digunakan sebagai penyuluhan kepada responden untuk membantu meningkatkan pengetahuan responden.

Hal diatas didukung dengan penelitian yang dilakukan oleh Hamdalah (2011) yang menyatakan bahwa efektivitas media permainan ular tangga lebih tinggi daripada media cerita bergambar dalam mempersepsikan pengetahuan, sikap, dan praktik kesehatan gigi dan mulut dengan nilai rata-rata pretest dari responden yang mendapatkan penyuluhan dengan media permainan ular tangga sebesar 7,69 berubah menjadi 11,53 pada nilai rata-rata post-test. Selain itu hal tersebut juga di dukung dengan penelitian yang dilakukan oleh Maisyaroh (2014) hasil penelitian peningkatan rata-rata pada siklus I yaitu 0,40 meningkat pada siklus II menjadi 0,64, hal tersebut menyatakan bahwa pelaksanaan pendekatan permainan ular tangga dapat meningkatkan hasil belajar siswa. 
Permainan ular tangga
sebagai bagian dari metode pendidikan kesehatan permainan simulasi merupakan salah satu bentuk proses belajar. Menurut Piaget (1980) mengemukaakan bahwa dasar dari belajar adalah aktivitas anak bila anak berinteraksi dengan lingkungan sosial dan lingkungan fisik ${ }^{[14]}$. Pendidikan kesehatan dengan metode simulasi permainan ular tangga dilakukan dalam kelompok-kelompok kecil, hal ini memberikan kesempatan bagi anak untuk berinteraksi dengan orang lain dan memungkinkan pertukaran ide-ide antar peserta melalui media ular tangga yang telah dimodifikasi sesuai dengan tujuan penelitian. Sehingga peserta mampu mengetahui informasi tentang kesehatan reproduksi terutama mengenai pernikahan usia muda dan HIV/AIDS yang baik dan benar. Kemudian terjadi peningkatan pengetahuan tentang kesehatan reproduksi. Responden yang memiliki pengetahuan kurang menjadi baik setelah diberikan intervensi. Dalam hasil penelitian ini dapat dilihat bahwa mayoritas responden yang mendapatkan penyuluhan dengan metode simulation game (permainan ular tangga) mengalami peningkatan pengetahuan yang lebih tinggi daripada responden yang mendapatkan penyuluhan dengan metode audio visual.

\section{SIMPULAN}

Terdapat perbedaan rata-rata skor pengetahuan pada pre test dan post test penyuluhan dengan menggunakan metode simulation game dan metode audio visual terhadap peningkatan pengetahuan remaja putri tentang kesehatan reproduksi di SMK Negeri 1 Pujon Kabupaten Malang dan metode yang pengaruhnya lebih tinggi dalam peningkatan pengetahuan kesehatan reproduksi remaja putri adalah metode simulation game.

\section{DAFTAR PUSTAKA}

[1] E. Kusmiran, Kesehatan Reproduksi Remaja dan Wanita. Jakarta: Salemba Medika, 2014.

[2] F. Efendi and Makhfudli, Teori dan Praktik Dalam Keperawatan. Jakarta: Salemba Medika, 2009.

[3] Badan Pusat Statistika Provinsi Jawa Timur, "Persentase Perempuan Jawa Timur Usia 10 Tahun ke Atas yang Kawin di Bawah Umur (Kurang dari 17 Tahun) menurut Kabupaten/Kota," 2013. [Online]. Available: https://jatim.bps.go.id/link-

TabelStatis/view/id/160. [Accessed: 25-May-2017].

[4] Dinas Kesehatan, "Profil Kesehatan Kabupaten Malang," 2016.

[5] Ditjen P2P Kementerian Kesehatan RI, "Laporan Situasi Perkembangan HIV-AIDS \& PIMS di Indonesia: April-Juni 2016," 2016. [Online]. Availablefrom:

http://www.aidsindonesia.or.id/ck_up loads/files/Laporan HIV AIDS TW 2 2016.pdf. [Accessed: 04-Mar-2017].

[6] S. Setiawan,. Dermawan. A.C, Proses Pembelajaran Dalam Pendidikan Kesehatan. Jakarta: Trans Info Media, 2008.

[7] N. A. Rizki, "Perbedaan Pengaruh Metode Focus Group Discussion (FGD) dengan Metode Simulation Game (SIG) Terhadap Peningkatan Pengetahuan Siswa Kelas XI Tentang Kesehatan Reproduksi Remaja (KRR) di SMK Hidayah Semarang," J. Kesehat. Masy., pp. 24-31, 2012.

[8] Nur Puspita Sari, "Studi Komparasi 
Penyuluhan Audio Visual dan Peer Group terhadap Tingkat Pengetahuan Kesehatan Reproduksi Remaja di SMP N 1 Ngaglik Sleman Yogyakarta," Stikes Aisyiyah, 2015.

[9] U. A. Yusuf Yasin, Sirkuit Pintar Melejitkan Kemampuan matematika dan bahasa inggris dengan metode ulartangga. Jakarta: Visimedia, 2011.

[10] A. Arsyad, Media Pembelajaran. Jakarta: Rajawali Pers, 2014.

[11] C. Amelia, "Efektivitas Permainan Ular Tangga Untuk Meningkatkan Pengetahuan Tentang Bahaya Merokok Siswa Kelas VII dan VIII SMP Ma'arif NU Tegal," Univ. Negeri Semarang, 2009.

[12] A. Hamdalah, "Perbedaan Efektivitas Metode Ceramah dengan Media Cerita Bergambar dan Media Permainan Ular Tangga dalam Meningkatkan Pengetahuan, Sikap, dan Praktik Kesehatan Gigi dan Mulut," Univ. Jember, 2011.

[13] I. Maisyaroh, "Penerapan Metode Permainan Ular Tangga (Snakes Ledder) untuk Meningkatkan Hasil Belajar Siswa pada Mata Pelajaran IPS," 2014.

[14] F. A. Nai, Teori Belajar dan Pembelajaran Implementasinya dalam Pembelajaran Bahasa Indonesia di SMP, SMA, dan SMK. Yogyakarta: Deepublish, 2017. 